\title{
Taxonomic, physical and morphological characterization of four species of agave with potential for the production of cellulose fibers from the leaves
}

DOI: $10.46932 /$ sfjdv3n1-099

Received in: Jan 30st, 2021

Accepted in: Feb 1th, 2022

\author{
Francisco Prieto García \\ Doctor en Química por la Universidad de Valladolid, España \\ Universidad Autónoma del Estado de Hidalgo \\ Carretera Pachuca-Tulancingo, km 4.5, C.P. 42076, Pachuca, Hidalgo, México \\ E-mail: prietog@uaeh.edu.mx
}

\section{Judith Prieto Méndez}

Doctora en Ciencias Ambientales por la Universidad Autónoma del estado de Hidalgo

Universidad Autónoma del Estado de Hidalgo

Carretera Pachuca-Tulancingo, km 4.5, C.P. 42076, Pachuca, Hidalgo, México

E-mail: jprieto@uaeh.edu.mx

\section{Edith Jiménez Muñóz}

Doctora en Ciencias Ambientales por la Universidad Autónoma del estado de Hidalgo

Universidad Autónoma del Estado de Hidalgo

Carretera Pachuca-Tulancingo, km 4.5, C.P. 42076, Pachuca, Hidalgo, México

\section{Otilo Arturo Acevedo Sandoval}

Doctor en Química por la Universidad Autónoma del estado de Hidalgo

Universidad Autónoma del Estado de Hidalgo

Carretera Pachuca-Tulancingo, km 4.5, C.P. 42076, Pachuca, Hidalgo, México

\section{Rodrigo Rodríguez Laguna}

Doctor en Ciencias con Especialidad en Manejo de Recursos Naturales. Facultad de Ciencias Forestales

de la Universidad Autónoma de Nuevo León.

Universidad Autónoma del Estado de Hidalgo

Carretera Pachuca-Tulancingo, km 4.5, C.P. 42076, Pachuca, Hidalgo, México

\begin{abstract}
The aim of the study was to characterize taxonomic, physical, and morphologically distinct species agaváceas tequila, mezcal and pulque grown in different regions of Mexico. Four species were evaluated Agave lechuguilla Torr., Agave salmiana B. Otto ex Salm-Dick, both from the state of Hidalgo; Agave angustifolia Haw. From the state of Oaxaca and Agave tequilana Weber, Var. Azul, Jalisco. The work was divided into two phases: botanical phase and physical study. In the botanical phase classification and taxonomic characterization of phenological, ecological and ethnobotanical database was revised. In the physical phase size and leaf characteristics of the plant is characterized. We analyzed moisture, fiber granulometry and scanning electron microscopy to assess fiber morphologies. From the results of physical characterization and fiber lengths found, we concluded that there is high potential to produce cellulose pulp. The species A. angustifolia and A. tequilana were presented minor percentage of sizes $<0.5 \mathrm{~mm}$ that could affect an alkaline pulping process. For the species A. tequilana $98.5 \%$ fibers $<1 \mathrm{~mm}$ being the majority corresponding to the fraction $0.5-1.0 \mathrm{~mm}(84.3 \%)$ which corresponds to a size suitable for
\end{abstract}


cellulosic pulp paper making was obtained. The species A. angustifolia showed $85.06 \%$ fibers $<1 \mathrm{~mm}$ fraction between $0.5-1.0 \mathrm{~mm}$ majority $(65.2 \%)$.

Keywords: A. salmiana, A. lechuguilla, Cellulose, A. angustifolia, Particle size.

\section{INTRODUCTION}

In the history of Mexico's agave (maguey) have played a major role and have 12.000 years old history. In Mexico before the Mexican Revolution the three major industries, making pulque, tequila and natural fiber cords, based their production on agaves (Colunga et al., 2007). Over a hundred years ago in Mexico occurred 300 million liters of tequila, a greater amount than is currently produced (CRT, 2008); 600 million liters per year and as $60 \%$ of the strings around the world were made of Mexican henequen: pulque yet occurred twice. As evidence of this greatness many pulque haciendas in Puebla, Tlaxcala, Hidalgo and henequen in Yucatan, there is a major tequila industry.

Research has been conducted concerning the fiber pulping tequilana agave bagasse to produce paper, for which techniques of mechanical, chemical, and biological pulping are used. The study showed that this application is feasible, but paper strength was low (Aguirre et al., 2001). This indicates that further studies to date are inconclusive. Recently, Parra and colleagues (Parra et al., 2010) conducted an investigation for drawing fibers from six species of Agave: three narrow blade (A. lechugilla, A. tequilana and A. angustifolia) and three with broad leaves (A American, A. salmiana and A. mapisaga) using different methods for the extraction of fibers. The results indicate that A. salmiana and A. mapisaga were the species with the best possible features for paper making, although these authors only presented results based handicrafts made from fibers were obtained. This work is the only thing that could be found in the literature review in which the production of fibers and probable pulping cellulose arises from the stalks or leaves, as most of the work reported refer to the residue bagasse obtained from the pineapple.

The objectives of this work are taxonomic, physical, and morphological characterization (Yusuf, 2018) of different species of agaváceas tequila, pulque and mezcal grown in different regions of the country. Later we will develop the study of new methods or variants of effective and economic techniques and optimization for the preparation and characterization of cellulose pulp from maguey species that serve to obtain at least handmade paper.

\section{MATERIALS AND METHODS}

\subsection{STUDY AREAS AND SAMPLING}

Sampling of four species of agaváceas were evaluated in this study. The collected samples were taken in the states of Hidalgo, Oaxaca and Jalisco. Mexico sampling was performed for species of at all places 
(Table 1) and in Fig. 1 an image is shown of locations. It is pertinent to mention that the species Agave tequilana Weber, Var. Azul not in the state of Hidalgo, which corresponds to that reported (Ruíz et al., 1999) who note that it is only cultivated in municipalities in the states of Jalisco, Guanajuato, Michoacan, Nayarit and Tamaulipas, despite that it adapts to a wide altitudinal range. Seems to be favored by the range of heights ranging from 700-2000 m (Vargas, 2004), which helps explain why it is not admissible in Hidalgo with altitudes between 2100 and 3500 meters.

Table 1. Geographical location of sampling points of Agavaceas.

\begin{tabular}{|c|c|c|c|}
\hline Variety & Location; State & Coordenates & $\begin{array}{c}\text { Altitude } \\
\text { (masl) }\end{array}$ \\
\hline Agave angustifolia Haw. & Zimatlán, Oaxaca & $16^{\circ} 45^{\prime} 05.4^{\prime \prime} \mathrm{N}$ and $96^{\circ} 49^{\prime} 47.8^{\prime \prime} \mathrm{O}$ & 1654 \\
\hline Agave lechuguilla Torr. & $\begin{array}{l}\text { San Agustín Tlaxiaca, } \\
\text { Hidalgo }\end{array}$ & $\begin{array}{l}20^{\circ} 05^{\prime} 26.5^{\prime \prime} \mathrm{N} \text { and } 98^{\circ} 52^{\prime} 19.5^{\prime \prime} \\
\mathrm{O}\end{array}$ & 2853 \\
\hline $\begin{array}{l}\text { Agave salmiana B. Otto ex Salm- } \\
\text { Dick }\end{array}$ & Epazoyucan, Hidalgo & $\begin{array}{l}20^{\circ} 00^{\prime} 02.5^{\prime \prime} \mathrm{N} \text { and } 98^{\circ} 36^{\prime} 28.9^{\prime \prime} \\
\mathrm{O}\end{array}$ & 2220 \\
\hline Agave tequilana Weber, Var. Azul & Tequila, Jalisco & $21^{\circ} 12^{\prime} 30^{\prime \prime} \mathrm{N}$ and $103^{\circ} 36^{\prime} 00^{\prime \prime} \mathrm{O}$ & 850 \\
\hline
\end{tabular}

This species $A$. Tequilana was collected in the town of Tequila in Jalisco. For this research work is divided into phases of specialties:

Botanical phase. In this phase the taxonomic classification of species of agaves of the study regions was performed, which allowed us to evaluate the potential for these species to achieve high efficiencies in obtaining cellulose pulp flagship species and decide on those most economic feasibilities.

Taxonomic classifications of the species under study, conducted in cabinet, through a review of literature (Gentry, 1982; Nobel, 2003; García, 2004) on phenology, ecology and ethnobotany. Later species were collected and their locations with geographic coordinates were recorded, as well as altitude, vegetation type and relative abundance. In the near population centers or urban locations locals were interviewed about the usefulness and origin of the observed maguey, through informal conversations, to avoid bias in the responses.

Fig. 1. Location of samples

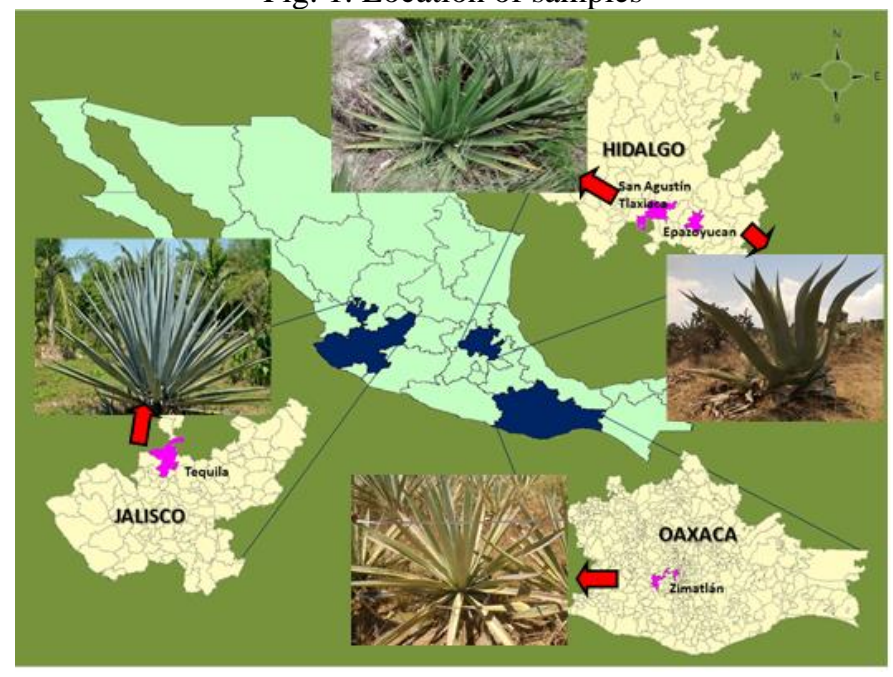


Physical phase. In this phase samples of species of agaves were subjected to a drying process (moisture determination) in order that these samples are subjected to an analysis of grinding and screening to define suitable particle sizes for further processing to obtain pulps. They were characterized in their dimensiones and other foliar characteristics of the leaves and the bases. Further samples were also analyzed by scanning electron microscopy (SEM) to specify the morphologies of observable fibers and analyzed particle sizes and distribution of the fibers.

Moisture analysis was carried out as specified in the NMX-F-211-2012 SCFI determination of moisture and volatile matter from the hot plate method. Morphological analysis of the screened product was performed using a scanning electron microscope (SEM) JEOL, JSM-820 Model. In this analysis the characteristics of the fibers were observed. The distribution and size of the particles of fibers obtained were evaluated by a laser diffraction analyzer ray equipment signature LS13-320 Beckman Coulter liquid with universal modules. Samples were suspended in distilled water and continuously stirred.

\section{RESULTS AND DISCUSSION}

\subsection{BOTANICAL PHASE}

Taxonomic classification of agaves in herbarium. Taxa or groups that living things are classified are structured in a hierarchy of inclusion, in which a group covers other minor and this, in turn, subordinate to a larger one. The groups are assigned a taxonomic rank or taxonomic category that accompanies the proper name of the group. Taxonomic categories under study are agaves (Colunga et al., 2007; García, 2010; Mora et al., 2011).

- Division: Angiospermae

- Class: Monocotiledoneae

- Order: Liliales

- Family: Agavaceae

- Subfamily: Agavoideae

- Genus: Agave

- Species: Agave sp.

\subsubsection{Phenological classification of agaves in herbarium}

a) Scientific name: Agave angustifolia Haw.

Name(s) common: Sculling Maguey or maguey mount in Oaxaca (Palma, 1991).

Status: None (NOM 1994 INE). 
Origin: North America (Pérez and Gallardo, 1997).

Biological Form: Shrub 1-2 m (Wickens et al., 1987).

Phenology: Leaves: The leaves can live between 5 and 8 years (Palma, 1991); Flowers: May to June (Wickens et al., 1987).

Distribution in Mexico: Vegetable Association savannas, thorn forests and tropical deciduous forests (Pérez and Gallardo, 1997)]. Forests of Quercus-Pinus, Quercus, tropical deciduous forest and secondary vegetation demolished (Wickens et al., 1987).

Environmental Requirements: Elevation (m): Average: 1,000; Low: 0, Maxima: 2,000 (Wickens et al., 1987). It was obtained in the town showing Zimatlan in Oaxaca at an altitude of 1654 meters.

Floors: Classification (FAO), Chromic Luvisol, Cambisol calcium (García, 2012); Physical Characteristics: Depth: From deep to moderately deep (Wickens et al., 1987); Texture: Arene silty, clayey never; Drainage: Well drained; Humidity apparent: little; Color: From dark brown to off-calcareous; Chemical characteristics; pH: 5-8.5; Organic matter: Moderate (Wickens et al., 1987); Temperature $\left(16^{\circ} \mathrm{C}\right.$, as ideal), Media: $20^{\circ} \mathrm{C}$ (García, 2012); Precipitation (mm), Media: 600 a 700, Minimmun: $<235$ (Palma, 1991); Maximum: not reported.

Other: This occurs well in frost-free area. Propagation: by runners sexual and asexual (Sánchez, 1989), and aproximis (Granados, 1993).

Collection and management of seed: Due to the long time required and the care you need, reproduction by seed (Granados, 1993) is not practiced. Time of collection and propagation: In the cloves after developing inflorescence (Pérez and Gallardo, 1997). The suckers and bulbils are planted in the period from May to June (Enriquez et al., 2005). Useful vegetative parts are bulbils (Pérez \& Gallardo, 1997), suckers (Sánchez, 1989).

Methods of production: the suckers and bulbils from the mother plant are extracted by a cut (Sánchez, 1989).

Conditioning plant prior to final transplant: battered leaves are removed, dried twigs and left exposed to the sun (Sánchez, 1989).

Preparing the ground: tracking and weeding. If the ground has weed problems is recommended manual or mechanical weeding depending on ground conditions. If this has slopes greater than $12 \%$ to avoid soil erosion is recommended, remove vegetation only at sites where plants, stripes or around strains were planted. This activity can be performed using veneering vegetation machetes or manually remove (Arriaga et al., 1994). Subsoiling: If the ground has weed problems is recommended for manual or mechanical weeding depending on ground conditions. If this has slopes greater than $12 \%$ to avoid soil erosion is recommended, remove vegetation only at sites where plants, stripes or around strains were 
planted. This activity may be conducted by means of veneering vegetation with machetes, or manually remove it (DOF, 2011). It is recommended strains of contour lines should be arranged on a staggered basis. The distance between contour lines depends on the slope and density of plants you want to set.

Opening of strains: 15 to $20 \mathrm{~cm}$ deep and 1.5 to $2 \mathrm{~m}$ apart (5). Depending on the terrain the size and type of strains may vary depending on soil conservation strategies that seek to use, the characteristics of the soil and climatic conditions (Arriaga et al., 1994).

It is convenient to build structures on the loading platform in order to accommodate two or more floors to optimize the capacity of vehicles and reduce transportation costs. In order to prevent the plant suffer less stress transport time ideally should not exceed 3 (Arriaga et al., 1994).

To protect the plantation against disturbance factors such as trampling and grazing of livestock, it is recommended to place a fence around the perimeter of the plantation (Arriaga et al., 1994).

Pests and diseases: the bacterium Erwinia carotovora (Rodríguez, 2006) and the black weevil attack (Scyphophorus acupunctatus) (=interstitialis) Gyllenhal) (Coleoptera: Curculionidae) (Solís et al., 2001; Bravo, 2003) are common and must be controlled.

b) Scientific name: Agave lechuguilla Torr.

Sinomia: Agave glomeruliflora Engelm. A. Berger (pro sp.). Agave heteracantha var. glomeruliflora Engelm. Agave lecheguilla forma A. glomeruliflora Berger (pro sp.) Trel.

Name(s) commun(es): Lechuguilla in the northern border states of Mexico, tzuta (Otomí language) - Hidalgo (Martínez, 2004), ixtle (Standley, 1961). Shows the municipality of San Agustín Tlaxiaca at an altitude of $2340 \mathrm{~m}$ was taken.

Status: Act for the sustainable management of the state of Hidalgo maguey (DOF, 2011).

Source: arid zones of North America.

Biologically form: Grass rosette of 50-70 cm (Ramirez, 1999).

Phenology: Sheets: Perennifolia, succulent leaves with thorns; Flowers: Each rosette blooms only once; between 6 and 15 years (Sánchez, 1993); Fruits: Capsules.

Distribution in Mexico: Vegetable Association in xeric scrub (Rzedowski, 1983). [Microphyll desert scrub and desert scrub rosetophilous (Sánchez, 1989).

Entities: Overall in the northern border states of Mexico, especially in Nuevo Leon, Coahuila, Tamaulipas (Ramirez, 1999), Durango (Hernández et al., 1991) and also reported for southern Hidalgo (Rzedowski, 1983).

Environmental Requirements: Altitude (m) Average: 2,400, Low: 2,250 (Rzedowski, 1983) and Maximum: 2,700. 
Floors: Classification (FAO), Feozem, Leptosol, Xerosol, yermosol (Verified with letter soil); Rendzina, Leptosol, Foezem, Vertisol, Castanozem (Sánchez, 1989).

Physical Characteristics: Depth: Shallow; Texture: sandy loam to clay-free; Pedregoso. Color: dark in Rendzina, dark-brown in Castanozem; Chemical properties pH: 7.5 to 9.4, Organic matter: 2.46\%; Salts: carbonates in high calcium carbonate content; Fertility Rendzina high fertility (Sánchez, 1989).

Other: Temperature $\left({ }^{\circ} \mathrm{C}\right)$ Media: $20^{\circ} \mathrm{C}$; Low: $-5^{\circ} \mathrm{C}$ High: $35^{\circ} \mathrm{C}$; Precipitation (mm) 105 to 600 (Sánchez, 1989; Ramirez, 1999).

It grows in soils of limestone origin and occasionally clay (Sánchez, 1989).

Mainly vegetative, sexual transmission; The optimum temperature for germination is $25-30^{\circ} \mathrm{C}$, germinated with high percentages of light (Baskin and Baskin, 1998). Right consistency to keep the seed in place, the volume should not vary drastically with changes in humidity, medium texture to ensure proper drainage and good moisture retention capacity.

Adequate fertility, free of salts and unmineralized organic matter. When the substrate is inert one 55:35:10 mixture of peat, vermiculite and perlite or perlite, is suitable (Arriaga et al., 1994). In asexual propagation is done by braces, layering, cuttings and stakes rackets.

Time of collection and propagation: Since the last week of February until the arrival of the first rains in May and June. Useful vegetative parts Hijuelos. Plants with better size and higher number of bunches are chosen, the shoot is removed with a crochet (Sánchez, 1989).

Since the cultivation of this species is recommended for dry areas, it will be difficult weed problems. If they exist, it is advisable to remove the weeds manually, before they produce seeds and leave the organic matter in the soil. Applies only when hardened shallow layers presented, $\leq 15 \mathrm{~cm}$; long as the present land slopes $\leq 10 \%$ (Ramirez, 1999).

Since the environmental conditions of arid zones, the density of growing plants is limited by water, and combined with the slow growth of this species, it may not make sense plowing and subsoiling. Probably more advisable strains and dikes to retain surface runoff individually for each plant. In any case it is not recommended to remove the original vegetation cover, nor the destruction of the solid crusts of the desert.

Opening of strains: in arid areas, it is advisable to place the floors below ground level, so that small hollows around plants forming. Also, you should raise a barrier semicircular slope, a few inches high, below where the plant is planted, so that works as a small dam. Organic matter deposited on the surface can reduce soil desiccation and aid in water infiltration.

Forest pests and diseases (Detection and control) The "Escamoles" Liometopum apiculatum y Peltophorus polymitus pierce the leaves and buds. Megathymus sp. auger buds. Scyphophorus intertitialis 
auger leaves. I also attack the fungus "damping off", Alternaria sp., and the mushroom "sooty mold", Apnodium sp. Others are weevil Lechuguilla, S. acupunctatus, and rodents (Sánchez, 1989).

Due to the low biomass accumulation and flammable material, which is typical of arid areas, conducting fire breaks is not necessary.

\section{c) Scientific name: Agave salmiana B. Otto ex Salm-Dick}

Sinomia: According to Mora (Mora et al., 2011), Agave salmiana Otto ex Salm-Dyck is a species of maguey with the morphological diversity, whose variants are located in environments with varying degrees of humanization, from rangeland purpose to plantations and agricultural areas. This species is notable for the abundance and distribution of its variants in many locations in Mexico, from Tlaxcala to Coahuila. In the geographic area of the Mexican plateau, particularly in regions of the state of San Luis Potosi, wild populations are located and cultivated A. salmiana (Mora et al., 2011), which have been described variants 'White', 'Chinese' and 'Smooth' used primarily for making mezcal. Its adult plants show morphological differences in their leaves and thorns in your side reaction temperature germination under laboratory conditions (Peña et al., 2006; Vázquez et al., 2011). Samples Epazoyucan the town of Hidalgo state, at an altitude of $2220 \mathrm{~m}$ was obtained.

Name(s) commun(es): green agave, meek maguey, pulque maguey.

Status: Act for the sustainable management of the state of Hidalgo maguey (Arriaga et al., 1994).

Origin: native to Mesoamerica distributed from $34^{\circ}$ north latitude to $60^{\circ}$ south latitude; coinciding in our country the center of origin to the center of species diversity.

Biological form: Ground commonly rosette; $80 \mathrm{~cm}$ to $2 \mathrm{~m}$ high by 1.2 to $2.5 \mathrm{~m}$ in diameter. Leaves: It has 10-20 leaves; are linear-lanceolate to $70 \mathrm{~cm}$ to $2 \mathrm{~m}$ long and 16-40 cm wide; fleshy or nearly rigid: their margins are horn-toothed at the apex and in the rest; light green, sometimes yellow-green or greenglaucous.

Inflorescence: scape, as panicle 3.5 to $8 \mathrm{~m}$ long, fleshy bracts from an indoor to green. Flowers: Yellow color, 7 to $11 \mathrm{~cm}$ long. Fruit: Capsular seeds. Seeds: Black 8 to $9 \mathrm{~mm}$ in length and 5 to $7 \mathrm{~mm}$ wide. Distinguishing Features: Rosetta up to $1.5 \mathrm{~m}$ in diameter, dark green leaves have two or three lines highlighted slightly near the spine.

Phenology: The characteristics of maguey led it to be a very popular species and therefore human intervention has spread to other parts of our country; has come to be grown in states like Guerrero and Oaxaca, a place where the production of mezcal is a very important activity.

Distribution in Mexico: Altiplano Potosi-Zacatecas 
Environmental Requirements: The atmosphere of Potosi-Zacatecas maguey mezcal has three operating stations: the first from March to June (dry), the second from July to October (rainy) and the third from November to February (cold), which affect productivity performance and flavorful (Aguirre et al., 2001).

Soil: Clayey and stony. They can stay very steep soils; Sun: Abundant, although you can put too pale sunshine. Water: Scarce. If water is applied regularly can grow faster.

d) Scientific name: Agave tequilana Weber, Var. Azul

Sinomia: Agave tequilana Weber Blue Agave variety belongs to the subgenus and Rigidae section, which also belong to a large number of species and mezcal fibreras extending in Mexico and Central America being absent in the United States. This group is recognizable by its narrow shape and very stiff leaves.

Name(s) commun (es): Maguey tequila, blue agave, blue tequilaza, Weber

Status: None

Origin: It is a plant belonging to the Agavaceae and native to North America (Gentry, 1982) family. It is distributed between 5 and 25 north latitude and subtropical regions adapted to semi-arid and sub-humid temperate thermal regime, semi or warm (Ruíz et al., 1999). The term implies semiarid atmosphere with 30 to 119 days in which the rain precitación is equal to or greater than the evapotranspiration potential, while the term humid means 120 to 180 days in this condition. Meanwhile, temperate, warm temperate and semi schemes involve an average annual temperature between 5 and $18^{\circ} \mathrm{C}$, between 18 and $22^{\circ} \mathrm{C}$ and $>22^{\circ} \mathrm{C}$, respectively (Medina et al., 1998; Ruíz et al., 1999; Iniguez et al., 2001). Samples of the municipality of Tequila, Jalisco state at an altitude of 850 masl was obtained.

Biological Form: Succulent plant radically extending from 1.2 to $1.8 \mathrm{~m}$ in length. Its stem is thick, short of $30-50 \mathrm{~cm}$. height at maturity. The leaves from 90 to $120 \mathrm{~cm}$. lanceolate, acuminate firm fibers, often rigidly straight, concave upward to horizontal; it is wider towards the middle of the blade, narrow and thick at base, usually glaucous blue to grayish green. The margin is straight or wavy challenging, teeth generally regular size and irregularly spaced, mostly 3 to $6 \mathrm{~mm}$. half length of the sheet. The thin, curved or hoses from low height of the pyramidal base color dark brown to apex, 1 to $2 \mathrm{~cm}$ long, rarely flattened or overtly long laced up, wide base, dark brown decurrent or decurrent. The inflorescence is a panicle of 5-6 ms high, densely ramosa along with 20 to 25 diffuse large umbels of green flowers and pink stamens. Flowers $68-75 \mathrm{~mm}$ long, with bracteoles on the pedicels 3-8 $\mathrm{mm}$ long. Ovary 32-38 $\mathrm{mm}$ long, with short cylindrical neck, inconstricto almost terminated tip on the base. Floral tube $10 \mathrm{~mm}$ wide, funeliforme furrowed, unequal petals $25-28 \mathrm{~mm}$ long and $4 \mathrm{~mm}$ wide, linear, erect at anthesis but quickly 
loose, then changing to brown and dry. Filaments of 45 to $50 \mathrm{~mm}$ in length, bent inward along the pistil inserts 5-7 $\mathrm{mm}$ near the base of the tube; anthers of $25 \mathrm{~mm}$ long. The fruit is an oval capsule briefly cusp (Arriaga et al., 1994; Ruíz, 2007).

Phenology: The characteristics of the agave has led it to be a very popular species. The tequilana Agave is monocarpic, flowering only once in its life and then dies. Flowering occurs after a decade. The plant produces a flower stalk a few meters high, with numerous umbels of greenish vertical tubular flowers. Pollination depends solely on a bat nivalis Leptonycteris a nectivoro filostómido.

Distribution in Mexico: Located in 180 municipalities in five Mexican states that are part of the Appellation of Origin Tequila as: Jalisco, Michoacán, Tamaulipas, Nayarit and Guanajuato. Only those municipalities can use the raw material for the production of Tequila.

Environmental Requirements: Presented from October to March, which has requirements of high relative humidity and average temperature between 15 and $22^{\circ} \mathrm{C}$. Rainfall between $700-1000$ mm (Ruíz et al., 1999). It is characterized by oval and cause dry gray spots on the leaves near the bud after bud reaches the leaves and moves towards the center thereof, and to the pineapple. Has poor tolerance to low temperatures. The absorption cell is halved when temperatures drop to the level of -6 . Agave is less tolerant to low temperatures (Agave sisalana) halved to $-6.4^{\circ} \mathrm{C}$ absorption cell and the two most tolerant agaves (Agave utahensis Agave parryi and) reduce its absorption cell to $-19^{\circ} \mathrm{C}$. Therefore tequilana probably can not be grown in regions where temperatures occasionally occur -7 or less.

Furthermore, this sheet can tolerate temperatures agave to 55 (Nobel et al., 1998). Thirteen of the 19 species of agave that have been examined to date have a higher tolerance to low temperatures tequilana Agave (Nobel et al., 1998). CO2 assimilation is favored by day / night temperatures and low to moderate decreases drastically in environments where temperatures day/night air are high. The daily net $\mathrm{CO}_{2}$ uptake over 24-hour periods for leaves of this species is higher for day / night $15^{\circ} \mathrm{C} / 5^{\circ} \mathrm{C}$ temperatures, decreasing $10 \%$ at $25 / 15^{\circ} \mathrm{C}$ and $72 \%$ at $35 / 25^{\circ} \mathrm{C}$ (Nobel et al., 1998). Q10 has an agave (Fractional Increase in respiration per $10^{\circ} \mathrm{C}$ increase in the temperature of the air) passing 2.17 average of 5 to $15^{\circ} \mathrm{C}, 2.55$ at from 15 to $25^{\circ} \mathrm{C}$ and 2.67 at from 25 to $35^{\circ} \mathrm{C}$ (Nobel et al., 1998). The basis for development of agave temperature was $11^{\circ} \mathrm{C}$, requiring 85 units heat to the issuance of an agave leaf 1 and 45 units heat agaves 7 years (Flores et al., 2002).

Floors: Agaves prefer medium textured soils, such as loam, sandy loam or clay loam. Even in areas with low rainfall prefer soils with better moisture retention, ie heavy textured soils (FAO, 1994, Delgado et al., 2021), such as clay or clay loam.

The agaves can develop properly from thin to deep soils. The genus Agave has a light to medium salt tolerance (FAO, 1994). The agaves thrive in a pH range of 6.0 to 8.0. They are not recommended soil 
acidity or alkalinity problems. You can develop in areas with high slope with very efficient surface drains and deemed unsuitable for traditional agriculture. However, under these conditions, soil conservation practices and water should be made to ensure a favorable environment for growing. In flat terrain is a risk of problems of waterlogging, which is harmful to the crop. Soils requires excellent good drainage (FAO, 1994).

\subsection{ETHNOBOTANICAL STUDY AGAVES RATING}

a) Scientific name: Agave angustifolia Haw.

From the sap concentrated in their apical meristem is that water areas where honey and pulque are produced. Its leaves are used for cooking meat on barbecue lamb and flowers in different dishes. In some parts of country flowers and leaves are used as fodder. In addition to the plant fibers are extracted to produce twine, baskets, clothing, sandals, toothbrushes, etc. Because of the high content of saponins it has been used to prepare soap or steroids or other sex hormones. It is used as a remedy for sprains or broken bones of humans or animals (Pérez and Gallardo, 1997).

b) Scientific name: Agave lechuguilla Torr.

Ixtle extraction is used for the manufacture of ties, LOMERAS, martingales, sacks, bales of cotton covers, rugs, among others (Ramirez, 1999). Root and stem products used in the manufacture of soaps (Sánchez, 1989) are obtained. The juice of the leaves can be used as detergent (Baskin and Baskin, 1998). It is used for the extraction of drugs (González, 1986).

\section{c) Scientific name: Agave salmiana B. Otto ex Salm-Dick}

"Mead" juice is used to make pulque. As forage, the leaves are eaten by cattle. Medicinally the "mead" is used to treat inflammation, as seen pulque is also used to increase blood. The leaves are used to treat gastritis, diabetes, buried grains, heal wounds and cough. It is also used in diseases of the digestive, endocrine, wounds and skin disorders, and respiratory system. It is one of the best alternatives for soil restoration, as it helps to control erosion and soil formation. They can be used for these purposes in a bit steep slope. In the Altiplano Potosi-Zacatecas, the "green maguey" is used (Agave salmiana ssp), as raw material for the production of pulque and mezcal, livestock feed and fuel material. In recent years its use has increased, which can cause severe ecological changes in ecosystems. Using GIS and forest sampling were quantified and some ecological attributes such as the degree of abundance, species richness, diversity index and an index of coverage of populations were found to change inhabiting the maguey in a communal farm region where they currently use (García et al., 2010) is performed. Its use is diverse and has played 
an important role in the life of the ancestors and the current inhabitants of Zacatecas Potosi region; today, its main use is for the production of mezcal (Zamora et al., 2010).

d) Scientific name: Agave tequilana Weber, Var. Azul

At the time tamping the earth, begins the long process of evolution Agave tequilana, which will take eight to ten years to gain maturity, during which they must be serviced; land clearing, fertilization, growth control and disease prevention. For high quality during the process must always be a careful selection of mother plants as well as suckers. During growth of the plant will perform some work help it to produce and maintain the maximum level of starch in the heart. At age six, to foster maturity of "escobeta barbeo" lowered, which consists of horizontal cuts on top of the leaves leaving the flat surface is performed. Almost to reach maturity, is becoming strictly barbeo until almost pineapple stop pads, this is called barbeo barbeo punished. After reaching maturity and in the dry months, the agave begins to reduce the size of their leaves in the Cogol or center, becoming smaller and more numerous by the growth of an inflorescence called quiote. This quiote grows rapidly and consume all sugars that accumulated over the years, so it is cut; This operation is called desquiote.

\subsection{PHYSICAL BLOCK}

\subsubsection{Physical characterization of agaves in studio.}

a) Agave tequilana Weber, Var. Azul

Results of characterization of the samples shown in (Table 2) for Agave tequilana Weber, Var. Azul which was sampled in the town of Tequila, Jalisco. On average 10 pads (leaves) shows that for its size (98.58 cm long, $8.33 \mathrm{~cm}$ wide and $2.08 \mathrm{~cm}$ thick) were similar to those reported by some authors (Velasco et al., 2008; Montañez et al., 2011); can only be analyzed in its thickness slightly thicker proved and therefore with higher volumes of leaves and bulk densities, which gives an idea that they are somewhat past maturity for jimado and cone collection, it can also be because the collection was conducted in the rainy season, which store water for periods of severe drought. Similarly the height of the plants are considered similar although slightly lower than that reported (Velasco et al., 2008) rosette diameter (see Fig. 2). 
Table 2. Physical characterization of tequilana Weber Agave, Var. Blue, taken in the town of Tequila, Jalisco. Species: Agave tequilana Weber, Var. Azul (Tequila) (Jalisco)

Leaves ( $=10$ leaves)

\begin{tabular}{|c|c|c|c|c|c|c|c|c|c|}
\hline \multicolumn{8}{|c|}{ Leaves $(n=10$ leaves $)$} & \multicolumn{2}{|c|}{ Roseta (n=6 plantas) } \\
\hline Values & $\begin{array}{l}\text { Long } \\
(\mathrm{cm})\end{array}$ & $\begin{array}{l}\text { width } \\
\text { (cm) }\end{array}$ & $\begin{array}{c}\text { thickness } \\
\text { (cm) }\end{array}$ & $\begin{array}{c}\text { mass } \\
(\mathrm{g})\end{array}$ & $\begin{array}{c}\text { Volume } \\
\left(\mathrm{cm}^{3}\right)\end{array}$ & $\begin{array}{l}\text { density } \\
\left(\mathrm{g} / \mathrm{cm}^{3}\right)\end{array}$ & $\begin{array}{c}\text { Folear area } \\
\left(\mathrm{cm}^{2}\right)\end{array}$ & $\begin{array}{l}\text { Plant height } \\
(\mathrm{mm})\end{array}$ & $\begin{array}{l}\text { Plant } \\
\text { diam. } \\
(\mathbf{m m})\end{array}$ \\
\hline average & 98.58 & 8.33 & 2.08 & 641.64 & 1741.92 & 0.38 & 827.59 & 1417.43 & 1469.48 \\
\hline S. dev. & 9.011 & 0.833 & 0.207 & 149.094 & 439.885 & 0.065 & 152.652 & 40.044 & 57.931 \\
\hline$\% \mathrm{VC}$ & 9.14 & 10 & 9.95 & 23.24 & 25.25 & 17.2 & 18.45 & 2.83 & 3.94 \\
\hline $\mathrm{tcal}$ & 2.055 & 2.187 & 7.341 & 1.403 & 3.896 & 5.12 & 0.24 & 1.377 & 18.042 \\
\hline $\mathrm{t} t a b$ & 2.262 & 2.262 & 2.262 & 2.262 & 2.262 & 2.262 & 2.262 & 2.262 & 2.262 \\
\hline Ref* & 100 & 7.5 & 1.6 & 575.47 & 1200 & 0.48 & 816 & 1400 & 1800 \\
\hline \multicolumn{10}{|c|}{ Species: Agave tequilana Weber, Var. Azul (Tequila) (Jalisco) } \\
\hline Values & $\begin{array}{c}\text { Moisture } \\
(\%)\end{array}$ & \multicolumn{2}{|c|}{$\begin{array}{c}\text { Granul. } \\
<0.5 \mathrm{~mm}(\%)\end{array}$} & \multicolumn{2}{|c|}{$\begin{array}{c}\text { Granul. } \\
\text { 0.5-1.0 mm (\%) }\end{array}$} & $\begin{array}{c}\text { Granul. } \\
>1.0 \mathrm{~mm} \\
(\%)\end{array}$ & $\begin{array}{l}\text { Color } \\
(1-6)\end{array}$ & $\mathbf{N}^{\circ}$ thorns & $\begin{array}{c}\text { Height } \\
\text { apical } \\
\text { spine }(\mathbf{c m})\end{array}$ \\
\hline average & 83.43 & \multicolumn{2}{|c|}{13.62} & \multicolumn{2}{|c|}{84.83} & 1.56 & 4.3 & 151.05 & 1.51 \\
\hline S. dev. & 3.405 & \multicolumn{2}{|c|}{5.315} & \multicolumn{2}{|c|}{5.914} & 0.87 & 0.458 & 21.65 & 0.07 \\
\hline$\% \mathrm{VC}$ & 4.08 & \multicolumn{2}{|c|}{39.03} & \multicolumn{2}{|c|}{6.97} & 55.86 & 10.66 & 14.33 & 4.64 \\
\hline $\mathrm{t}$ cal & 3.182 & \multicolumn{2}{|c|}{-} & \multicolumn{2}{|c|}{0.091} & - & 2.07 & 0.153 & 22.136 \\
\hline $\mathrm{t} t a b$ & 2.262 & \multicolumn{2}{|c|}{2.262} & \multicolumn{2}{|c|}{2.262} & 2.262 & 2.262 & 2.262 & 2.262 \\
\hline Ref* & 80 & \multicolumn{2}{|c|}{ NR } & \multicolumn{2}{|c|}{$>85 \%$} & NR & 4 & 150 & 2 \\
\hline
\end{tabular}

* The references were taken from Montañez et al., 2011. NR: No Reported

Fig. 2. Sampling of Agave tequilana Weber, Var. Blue in the municipality of Tequila, state of Jalisco.

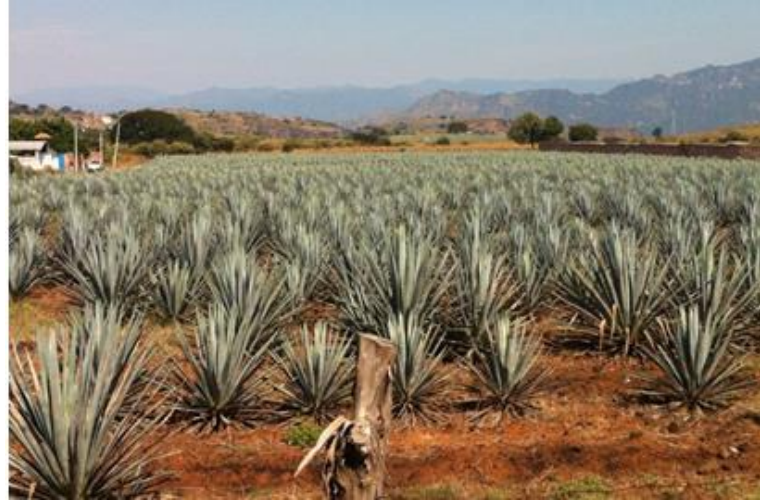

The moisture contents in the leaves were slightly higher $(83.43 \%)$ relative to what they report the authors consulted [45-46], which is related to have been collected in time rainy. Similarly can be considered a bit high color of the leaves collected, because when compared on a scale 1-6 with an average value of 4.31, as established and Reyes et al., 2000, this value should be between 3-4 (3.5 average collected several leaves) as an indication of sufficient maturity of the plant, which must correspond to an age of 8-10 years (optimal age for jima and production of tequila).

If colors are found under 3 in that scale, presupposes not mature enough or not age appropriate plant. Greater than 4, indicate that it is more mature than required, which is reflected in higher contents of sugars to the leaves, which based on what they make pineapples; this goes to the production of tequila (lower alcohol content). As for the height of the apical spine, corresponds with that reported by Montañez et al., (2011) but slightly smaller than indicated (Aguilar, 2011). 
Once dried the leaves are ground and sieved, the composition particle size fractions were analyzed. Was obtained $98.5 \%<1 \mathrm{~mm}$ fraction being the majority of effect $0.5-1.0 \mathrm{~mm}(84.3 \%)$ which corresponds with that reported by Águilar (2011). The fraction $<0.5 \mathrm{~mm}$ should vary between $8-10 \%$ and an average value slightly higher (13.6\%) was obtained but is not expected to affect to the pulping process in fiber length. In Fig. 3 the size distribution of particles of the fine fraction $(<0.5 \mathrm{~mm})$ and the fraction 0.5-1.0 $\mathrm{mm}$ was observed. As you can see the prevailing size was $324.4 \mu \mathrm{m}$ for the smallest (a) fraction, while for the majority fraction (b) was $932 \mu \mathrm{m}$ y shows inhomogeneous distribution. Fig. 4 shows the photomicrograph of the fibers of the major fraction; one can see that is heterogeneous in size.

Fig. 3. Distribution and sizes of dry particles of the fractions of a) $<0.5 \mathrm{~mm}$ and b) $0.5-1.0 \mathrm{~mm}$, of leaves of Agave tequilana Weber, Var. Blue in the municipality of Tequila, state of Jalisco.
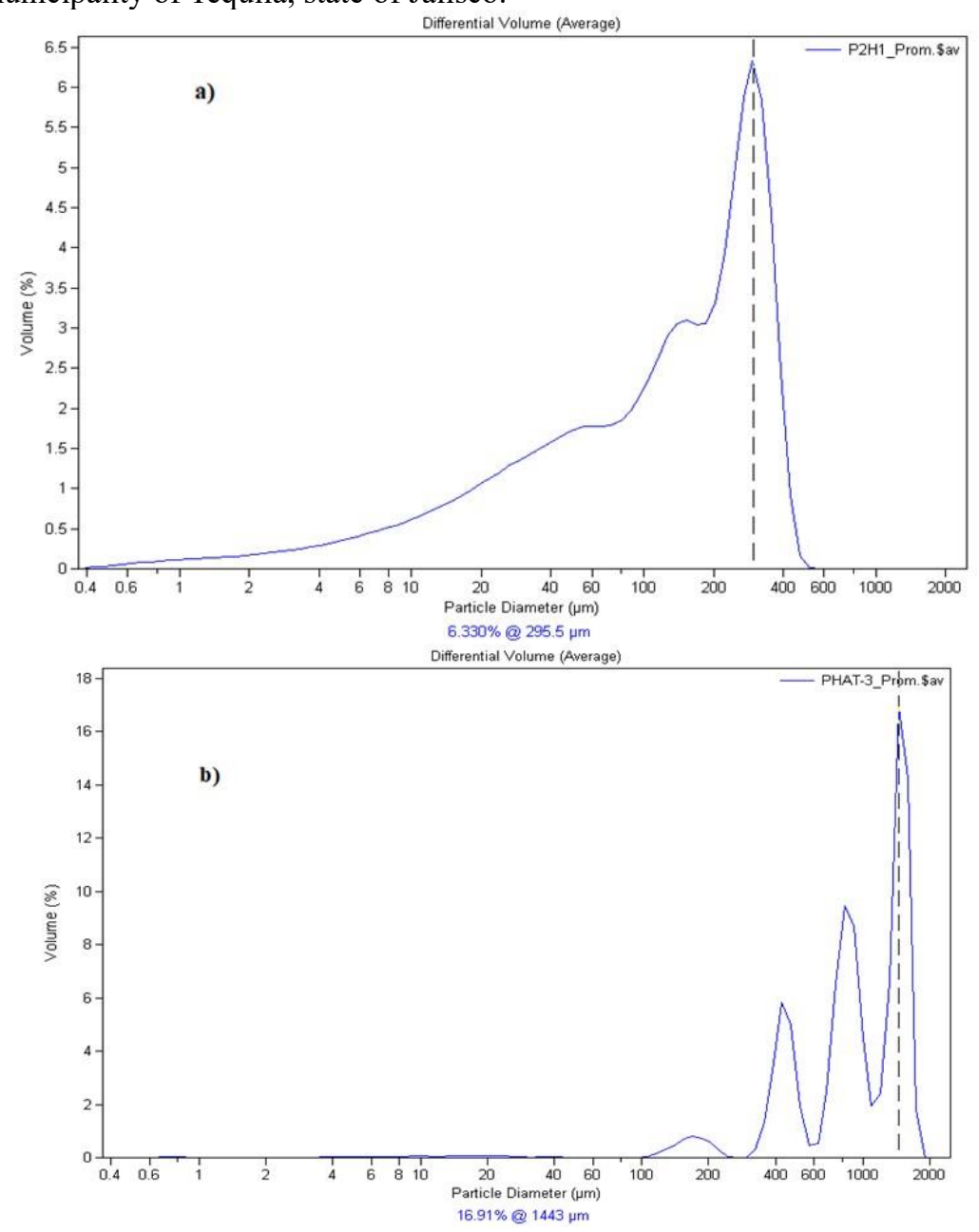
Fig. 4. Microphotography of fiber particles 0.5-1.0 mm, from Agave tequilana Weber leaves, Var. Blue in the municipality of Tequila, state of Jalisco.

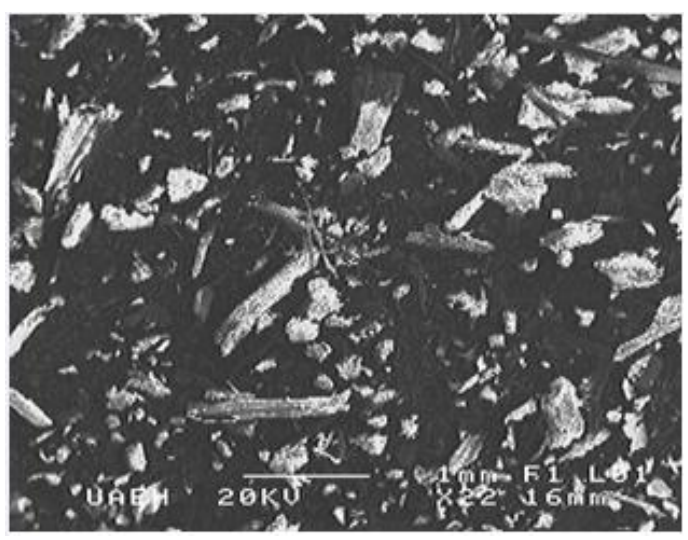

\section{b) Agave salmiana B. Otto ex Salm-Dick}

Table 3 shows the results of physical characterization of the range are reflected Agave Salmiana Otto ex Salm-Dyck, samples taken in the town of Epazoyucan, Hidalgo. Similarly as above, by an average of 10 sheets, you can see that there are no statistically significant differences in the length of their leaves and corresponds to what some authors reported (Parra et al., 2010; Mora, 2012) indicating values of 150 $\pm 1 \mathrm{~cm}$. However the mean values in leaf width $(21.23 \mathrm{~cm})$ was slightly lower than indicated some previous authors $24 \pm 2 \mathrm{~cm}$ (Silos et al., 2010). An important variation is observed as the thickness of the leaves was on average $6.5 \mathrm{~cm}$, much higher than the reported average $(4.5 \mathrm{~cm})$.

In terms of average mass, it was found that they are also higher in average weight $(9179 \mathrm{~g})$ than expected, attributed to the greater amount of water retained due to the time of sampling with high incidence of rainfall and corresponding with the greatest widths and thicknesses of the sheets. Similarly they were 1.37 times more bulky than what is reported in the references consulted $\left(1600-1700 \mathrm{~cm}^{3}\right)$. Consequently a slightly lower density but without statistical significance. If we observed a greater height (thinness) of the plant and increased rosette diameter in the groove (see Fig. 5), approximately $200 \mathrm{~cm}$ taller and wider rosettes.

Fig. 5. Sampling of Agave salmiana B. Otto ex Salm-Dick in the municipality of Epazoyucan, Hidalgo state.

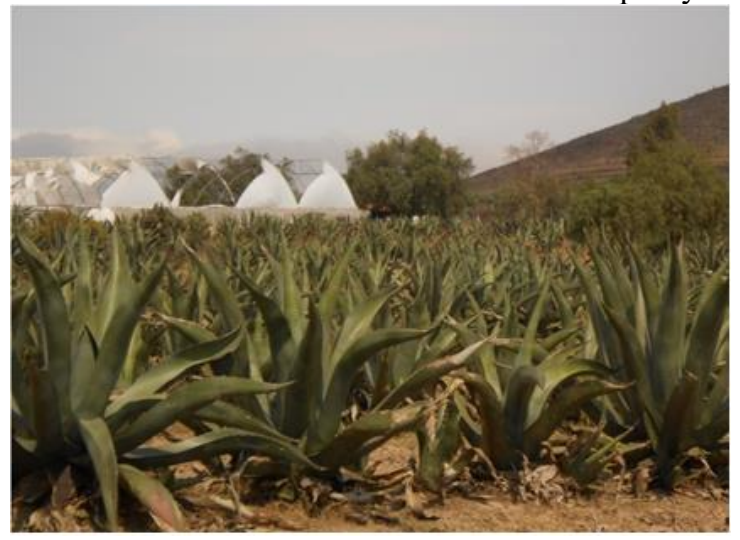


Table 3. Physical characterization of Agave salmiana B. Otto ex Salm-Dick, taken in the town of Epazoyucan, Hidalgo. Species: Agave salmiana B. Otto ex Salm-Dick (Pulque) (Hidalgo)

\begin{tabular}{|c|c|c|c|c|c|c|c|c|c|}
\hline \multicolumn{8}{|c|}{ Leaves ( $n=10$ leaves) } & \multicolumn{2}{|c|}{ Roseta (n=6 plants) } \\
\hline Values & $\begin{array}{c}\text { Long } \\
\text { (cm) }\end{array}$ & $\begin{array}{c}\text { width } \\
(\mathrm{cm})\end{array}$ & $\begin{array}{l}\text { thickness } \\
\text { (cm) }\end{array}$ & $\begin{array}{c}\text { mass } \\
(\mathrm{g})\end{array}$ & $\begin{array}{c}\text { Volume } \\
\left(\mathrm{cm}^{3}\right)\end{array}$ & $\begin{array}{l}\text { density } \\
\left(\mathrm{g} / \mathrm{cm}^{3}\right)\end{array}$ & $\begin{array}{l}\text { Folear area } \\
\qquad\left(\mathrm{cm}^{2}\right)\end{array}$ & $\begin{array}{c}\text { Plant } \\
\text { height } \\
(\mathrm{mm})\end{array}$ & $\begin{array}{c}\text { Plant diam. } \\
\text { (mm) }\end{array}$ \\
\hline average & 159 & 21.23 & 6.54 & 9179.36 & 22821.48 & 0.43 & 3397.78 & 2236.17 & 2488.83 \\
\hline S. dev. & 15.593 & 1.555 & 1.248 & 2281.693 & 7474.732 & 0.125 & 567.37 & 161.31 & 336.553 \\
\hline$\% \mathrm{VC}$ & 9.81 & 7.33 & 19.09 & 24.86 & 32.75 & 28.71 & 16.7 & 7.21 & 13.52 \\
\hline $\mathrm{t}$ cal & 1.825 & 6.659 & 5.165 & 1.912 & 2.632 & 0.903 & 1.545 & 4.63 & 2.714 \\
\hline t tab & 2.262 & 2.262 & 2.262 & 2.262 & 2.262 & 2.262 & 2.262 & 2.262 & 2.262 \\
\hline Ref* & 150 & 24.5 & 4.5 & 7800 & 16600 & 0.47 & 3675 & 2000 & 2200 \\
\hline
\end{tabular}

Species: Agave salmiana B. Otto ex Salm-Dick (Pulque) (Hidalgo)

\begin{tabular}{|c|c|c|c|c|c|c|c|}
\hline Values & $\begin{array}{c}\text { Moisture } \\
(\%)\end{array}$ & $\begin{array}{c}\text { Granul. } \\
<0.5 \mathrm{~mm}(\%) \\
\end{array}$ & $\begin{array}{c}\text { Granul. } \\
\text { 0.5-1.0 mm (\%) }\end{array}$ & $\begin{array}{c}\text { Granul. } \\
>1.0 \mathrm{~mm}(\%) \\
\end{array}$ & $\begin{array}{l}\text { Color } \\
(1-6)\end{array}$ & $\mathrm{N}^{\circ}$ thorns & $\begin{array}{c}\text { Height apical } \\
\text { spine }(\mathrm{cm})\end{array}$ \\
\hline average & 92.31 & 25.16 & 70.18 & 4.66 & 3.75 & 111.4 & 5.85 \\
\hline S. dev. & 1.886 & 3.119 & 4.723 & 2.52 & 0.403 & 8.888 & 0.709 \\
\hline$\% \mathrm{VC}$ & 2.04 & 12.4 & 6.73 & 54.07 & 10.75 & 7.98 & 12.12 \\
\hline $\mathrm{t}$ cal & 12.255 & - & 9.923 & - & 1.961 & 4.056 & 0.669 \\
\hline $\mathrm{t}$ tab & 2.262 & 2.262 & 2.262 & 2.262 & 2.262 & 2.262 & 2.262 \\
\hline Ref* & 85 & NR & $>85 \%$ & NR & 4 & 100 & 6 \\
\hline
\end{tabular}

* The references were taken from Mora et al., 2011. NR: No Reporte

The moisture contents in the range $A$. salmiana have a 7\% higher than the values reported Silo et $a l .,(2010)$ reached an average of $92 \%$, considered to be due to the season in which the samples were taken high rainfall.

The sizes and distribution of pre-dried and ground particles of the major fraction between 0.5-1.0 mm, was 70.8\% (Fig. 6 a); the particle size distribution of $<0.5 \mathrm{~mm}$ (with $25 \%$ in total, is also expected to not affect much in the pulping) shown in Fig. 6 b. Similar to that obtained with A. tequilana almost homogeneous distribution is observed but with a predominant particle size of 429.2 .mu.m (like fashion value) for the smallest and 905.1 for the major fraction .mu.m fraction. Fig. 7 shows the photomicrograph of the fibers of the major fraction.

c) Agave angustifolia Haw

Table 4 shows the results of the physical characterization of Agave angustifolia Haw variety, taken in the town of Zimatlán, state of Oaxaca (Fig. 8) is shown.

Also averaged 10 leaves collected shows that there are significant differences in the length and thickness of leaves relative to those reported by other authors (Garcia et al, 2010; Parra et al., 2010) in this paper sheet $102 \mathrm{~cm}$ in length on average shorter than the reported $125 \mathrm{~cm}$ are obtained and yet slightly greater thickness $(2.12 \mathrm{~cm})$ in relation to what is reported $(2.0 \mathrm{~cm})$ by previous authors. On the other hand the density of these leaves was lower than that reported $\left(0.313 \mathrm{~g} / \mathrm{cm}^{3}\right)$. Regarding other measurements only lower values are seen in terms of the height and diameter of the rosette plant.

The moisture contents are reported slightly above those reported by Garcia Mendoza $(2004,2010)$, probably because the sampling was done in times of heavy rains. 
The sizes and distribution of pre-dried and ground particles of the major fraction between 0.5-1.0 $\mathrm{mm}$ was $65.17 \%$ for the minor fraction $(<0.5 \mathrm{~mm})$ was approximately $20 \%$, the distribution and size of the ultimate particles are seen in Fig. 9.

Fig. 6. Distribution and sizes of dry particles of the minor $(<0.5 \mathrm{~mm})$ and majority $(0.5-1.0 \mathrm{~mm})$ fractions of leaves of Agave salmiana B. Otto ex Salm-Dick, taken in the municipality of Epazoyucan, Hidalgo.
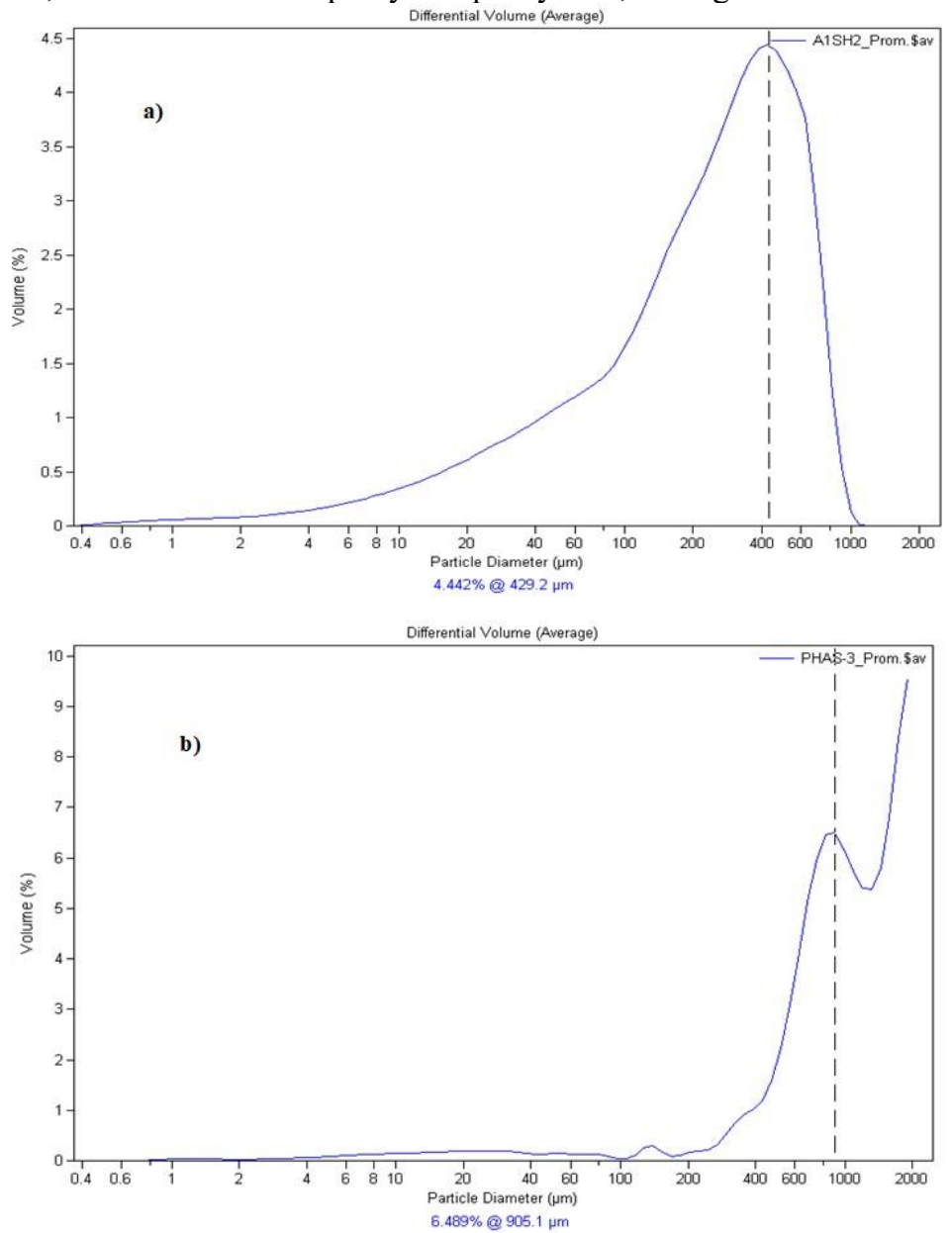

Fig. 7. Microphotography of fiber particles $0.5-1.0 \mathrm{~mm}$, from sheets of Agave salmiana B. Otto ex Salm-Dick in the municipality of Epazoyucan, Hidalgo state.

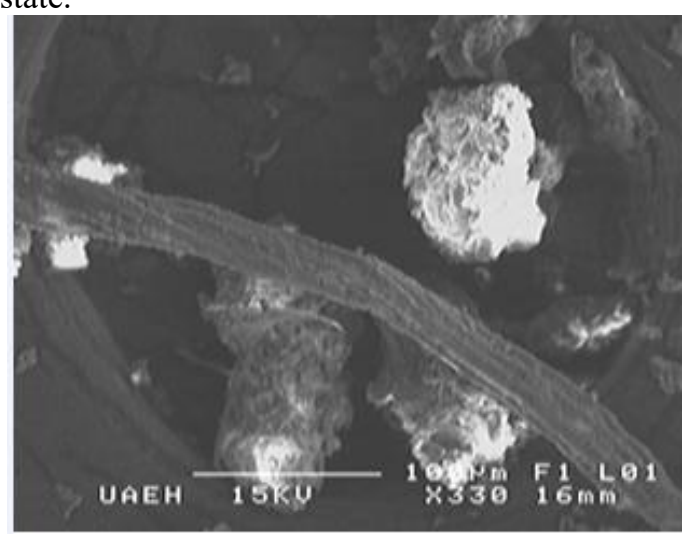




\begin{tabular}{|c|c|c|c|c|c|c|c|c|c|}
\hline \multicolumn{10}{|c|}{ Species: Agave angustifolia Haw (Mezcal) (Oaxaca) } \\
\hline & \multicolumn{6}{|c|}{ Leaves $(n=10$ leaves $)$} & \multicolumn{3}{|c|}{ Roseta ( $n=6$ plants) } \\
\hline Values & $\begin{array}{l}\text { Long } \\
(\mathrm{cm})\end{array}$ & $\begin{array}{c}\text { width } \\
(\mathrm{cm})\end{array}$ & $\begin{array}{c}\text { thickness } \\
\text { (cm) }\end{array}$ & $\begin{array}{c}\text { mass } \\
\text { (g) }\end{array}$ & $\begin{array}{l}\text { Volume } \\
\left(\mathrm{cm}^{3}\right)\end{array}$ & $\begin{array}{l}\text { density } \\
\left(\mathrm{g} / \mathrm{cm}^{3}\right)\end{array}$ & $\begin{array}{c}\text { Folear } \\
\text { area } \\
\left(\mathrm{cm}^{2}\right) \\
\end{array}$ & $\begin{array}{c}\text { Plant } \\
\text { height } \\
(\mathrm{mm}) \\
\end{array}$ & $\begin{array}{c}\text { Plant diam. } \\
\text { (mm) }\end{array}$ \\
\hline average & 102 & 6.16 & 2.12 & 427.67 & 1349.22 & 0.313 & 636.45 & 1484.17 & 2225.35 \\
\hline S. dev. & 9.754 & 0.65 & 0.087 & 116.497 & 282.172 & 0.03 & 126.335 & 130.539 & 193.818 \\
\hline$\% \mathrm{VC}$ & 9.56 & 10.54 & 4.09 & 27.24 & 20.91 & 9.46 & 19.85 & 8.8 & 8.71 \\
\hline t cal & 7.456 & 1.65 & 4.26 & 2.235 & 1.112 & 10.127 & 2.101 & 2.806 & 3.677 \\
\hline $\mathrm{t}$ tab & 2.262 & 2.262 & 2.262 & 2.262 & 2.262 & 2.262 & 2.262 & 2.262 & 2.262 \\
\hline Ref* & 125 & 6.5 & 2 & 510 & 1250 & 0.408 & 552.5 & 1600 & 2000 \\
\hline \multicolumn{10}{|c|}{ Species: Agave angustifolia Haw (Mezcal) (Oaxaca) } \\
\hline Values & $\begin{array}{r}\text { Moist } \\
(\%\end{array}$ & ture & $\begin{array}{c}\text { Granul. } \\
<0.5 \\
\mathrm{~mm}(\%)\end{array}$ & $\begin{array}{c}\text { Granul. } \\
\text { 0.5-1.0 mn } \\
(\%) \\
\end{array}$ & & $\begin{array}{l}\text { ranul. } \\
1.0 \mathrm{~mm} \\
(\%)\end{array}$ & $\begin{array}{l}\text { Color } \\
(1-6)\end{array}$ & $\mathbf{N}^{\circ}$ thorns & $\begin{array}{l}\text { Height apical } \\
\text { spine }(\mathbf{c m})\end{array}$ \\
\hline average & $\overline{72.8}$ & & 19.89 & 65.17 & & 5.69 & 4 & 79.75 & 2.42 \\
\hline S. dev. & 6.5 & & 5.825 & 6.366 & & 2.618 & 0.15 & 3.894 & 0.1166 \\
\hline$\% \mathrm{VC}$ & 9.0 & & 29.29 & 9.77 & & 46.05 & 3.8 & 4.88 & 4.82 \\
\hline $\mathrm{t}$ cal & 1.3 & & - & 4.883 & & - & 1.054 & 0.203 & 2.169 \\
\hline $\mathrm{t} t a b$ & 2.26 & & 2.262 & 2.262 & & 2.262 & 2.262 & 2.262 & 2.262 \\
\hline Ref* & 70 & & - & 75 & & - & 4 & 80 & $2.5^{\prime}$ \\
\hline
\end{tabular}

Fig. 8. Sampling of Agave angustifolia Haw., Taken in the municipality of Zimatlán, Oaxaca.

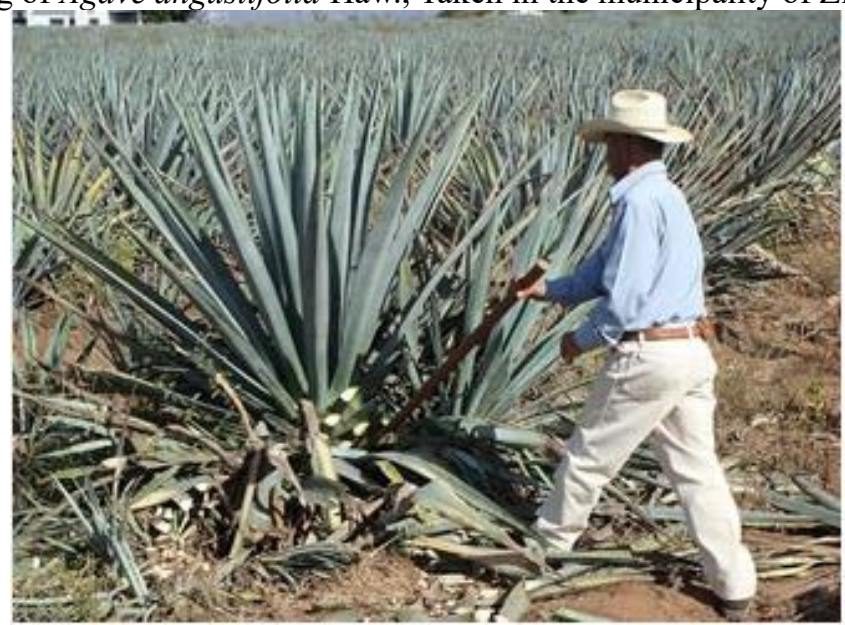

A distribution which is almost similarly uniform but with a predominant size slightly larger particles for $517.2 \mu \mathrm{m}$ and $993.6 \mu \mathrm{m}$ minor fraction to the $0.5-1.0 \mathrm{~mm}$ fraction is appreciated. As for the color of the leaves, they are considered adequate maturity age (values between 3-4, according to color scale (Reyes et al., 2000)) with an average value of 3.70. These leaves had a greater number of lateral spines (111 average) than reported $(\approx 100)$ Silo et al., $(2010)$, however the average height of the apical spine $(5.85 \mathrm{~cm})$ if the parameter corresponds to these same authors refer $(\approx 6.0 \mathrm{~cm})$. Fig. 10 shows a photomicrograph of the fibers of the major fraction. 
Fig. 9. Distribution and sizes of dry particles of the minor $(<0.5 \mathrm{~mm})$ and majority $(0.5-1.0 \mathrm{~mm})$ fractions of leaves of Agave angustifolia Haw., Taken in the municipality of Zimatlán, Oaxaca.
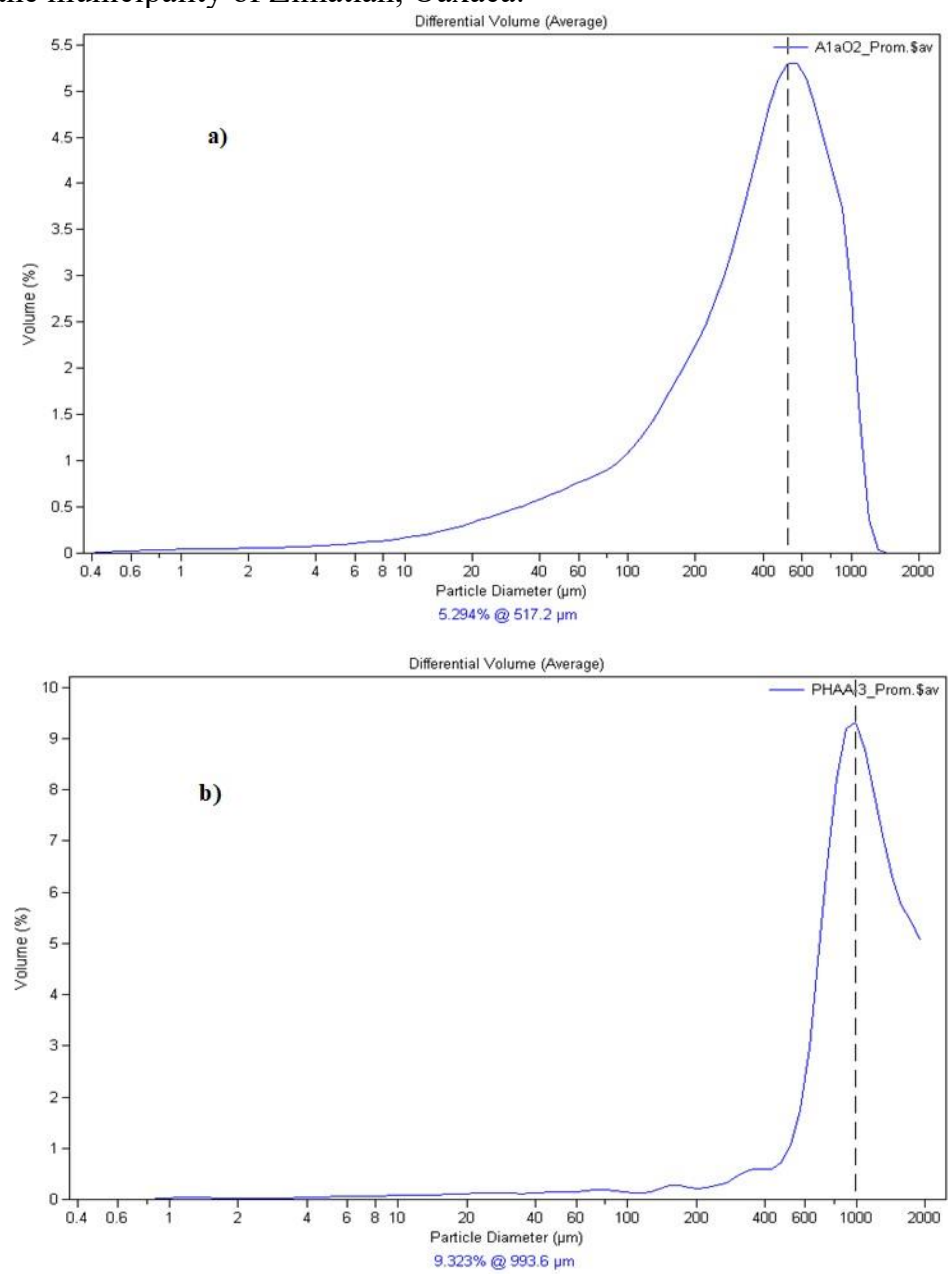

Fig. 10. Microphotography of fiber particles 0.5-1.0 mm, of leaves of Agave angustifolia Haw., Taken in the municipality of Zimatlán, Oaxaca.

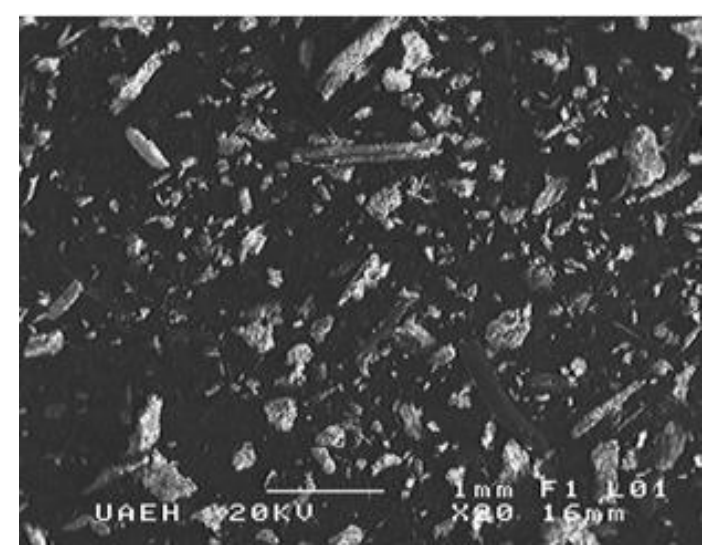

d) Agave lechuguilla Torr.

Table 5 shows the results of the physical characterization of the variety Agave lechuguilla Torr is., Taken in the town of San Agustin Tlaxiaca, Hidalgo (Fig. 11). Also averaging 10 collected sheets can be seen that there are several significant differences, except for the width and mass of the leaves, in all the other parameters are different. With respect to those reported by other authors (Mora, 2012; Gutiérrez et 
al., 2012); in this work leaves shorter, thinner, smaller volume, higher density and higher leaf area is obtained. Regarding measurements of the height and diameter of the rosette plant no significant differences. The moisture contents similarly were higher than expected, because of the same reason above.

\begin{tabular}{|c|c|c|c|c|c|c|c|c|c|}
\hline \multicolumn{10}{|c|}{ Species: Agave lechuguilla Torr. (fibras) (Hidalgo) } \\
\hline \multicolumn{7}{|c|}{ Leaves $(\mathrm{n}=10$ leaves $)$} & \multicolumn{3}{|c|}{ Roseta ( $\mathrm{n}=6$ plants) } \\
\hline Values & $\begin{array}{l}\text { Long } \\
(\mathrm{cm})\end{array}$ & $\begin{array}{c}\text { width } \\
\text { (cm) }\end{array}$ & $\begin{array}{c}\text { thickness } \\
(\mathrm{cm})\end{array}$ & $\begin{array}{c}\text { mass } \\
(\mathrm{g})\end{array}$ & $\begin{array}{c}\text { Volume } \\
\left(\mathrm{cm}^{3}\right)\end{array}$ & $\begin{array}{l}\text { density } \\
\left(\mathrm{g} / \mathrm{cm}^{3}\right)\end{array}$ & $\begin{array}{c}\text { Folear } \\
\text { area } \\
\left(\mathrm{cm}^{2}\right)\end{array}$ & $\begin{array}{l}\text { Plant height } \\
(\mathrm{mm})\end{array}$ & $\begin{array}{l}\text { Plant diam. } \\
(\mathbf{m m})\end{array}$ \\
\hline average & 39.83 & 4 & 0.66 & 91.04 & 104.83 & 0.87 & 159.4 & 58.67 & 91.33 \\
\hline S. dev. & 2.177 & 0.229 & 0.08 & 12.529 & 16.619 & 0.05 & 12.352 & 2.156 & 3.194 \\
\hline$\% \mathrm{VC}$ & 5.46 & 5.71 & 12.23 & 13.76 & 15.85 & 5.67 & 7.75 & 3.68 & 3.5 \\
\hline $\mathrm{t}$ cal & 7.506 & 0.061 & 5.698 & 0.263 & 7.454 & 15.856 & 15.739 & 1.955 & 1.32 \\
\hline $\mathrm{t}$ tab & 2.262 & 2.262 & 2.262 & 2.262 & 2.262 & 2.262 & 2.262 & 2.262 & 2.262 \\
\hline Ref* & 45 & 4 & 0.8 & 90 & 144 & 0.63 & 97.92 & 60 & 90 \\
\hline \multicolumn{10}{|c|}{ Species: Agave lechuguilla Torr. (fibras) (Hidalgo) } \\
\hline Values & \multicolumn{2}{|c|}{$\begin{array}{c}\text { Moisture } \\
(\%)\end{array}$} & $\begin{array}{c}\text { Granul. } \\
<0.5 \mathrm{~mm} \\
(\%)\end{array}$ & \multicolumn{2}{|c|}{$\begin{array}{c}\text { Granul. } \\
0.5-1.0 \mathrm{~mm}(\%)\end{array}$} & $\begin{array}{l}\text { Granul. } \\
>1.0 \mathrm{~mm} \\
(\%)\end{array}$ & $\begin{array}{l}\text { Color } \\
(1-6)\end{array}$ & $\mathbf{N}^{\circ}$ thorns & $\begin{array}{c}\text { Height } \\
\text { apical spine } \\
(\mathrm{cm})\end{array}$ \\
\hline average & \multicolumn{2}{|c|}{76.08} & 41.8 & \multicolumn{2}{|c|}{46.92} & 11.29 & 3.5 & 27.33 & 1.87 \\
\hline S. dev. & \multicolumn{2}{|c|}{1.23} & 6.527 & \multicolumn{2}{|c|}{8.266} & 7.299 & 0 & 2.54 & 0.227 \\
\hline$\% \mathrm{VC}$ & \multicolumn{2}{|c|}{1.62} & 15.62 & \multicolumn{2}{|c|}{17.62} & 64.65 & 0 & 9.29 & 12.16 \\
\hline $\mathrm{t}$ cal & \multicolumn{2}{|c|}{15.638} & - & \multicolumn{2}{|c|}{10.744} & - & 0 & - & 1.858 \\
\hline t tab & \multicolumn{2}{|c|}{2.262} & 2.262 & \multicolumn{2}{|c|}{2.262} & 2.262 & 2.262 & 2.262 & 2.262 \\
\hline Ref* & \multicolumn{2}{|c|}{70} & NR & \multicolumn{2}{|l|}{75} & NR & 3.5 & NR & 2 \\
\hline
\end{tabular}

* The references were taken from Gutiérrez et al., 2012. NR: No Reported

The size and distribution of particles previously dried and ground of the major fraction between 0.5-1.0 mm was 46.92\%, a figure much lower than expected at reporting Reyes et al., 2000, who indicate an approximate value $75 \%$ and the lowest in all varieties. For the minor fraction $(<0.5 \mathrm{~mm})$ a very high value of $41.8 \%$, although there is an expected value for this fraction is considered that if time could affect the pulping of cellulose for low size was obtained.

The distribution and size of the ultimate particles are observed in Fig. 12 a and b. An almost homogeneous distribution shown but with a slightly larger size of predominant particles and 567.7 .mu.m for 1091 .mu.m minority and majority fraction to fraction; by results is similar to the variety $A$. angustifolia.

Fig. 11. Sampling of Agave lechuguilla Torr., Taken in the municipality of San Agustín Tlaxiaca, Hidalgo.

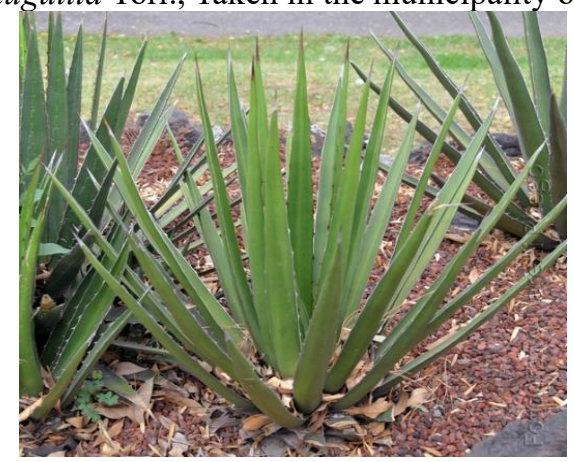


Fig. 12. Distribution and sizes of dry particles of minor fractions a) $<0.5 \mathrm{~mm}$ and majority b) $0.5-1.00 \mathrm{~mm}$ of leaves of $\mathrm{Agave}$ lechuguilla Torr., Taken in the Municipality of San Agustín Tlaxiaca, Hidalgo.
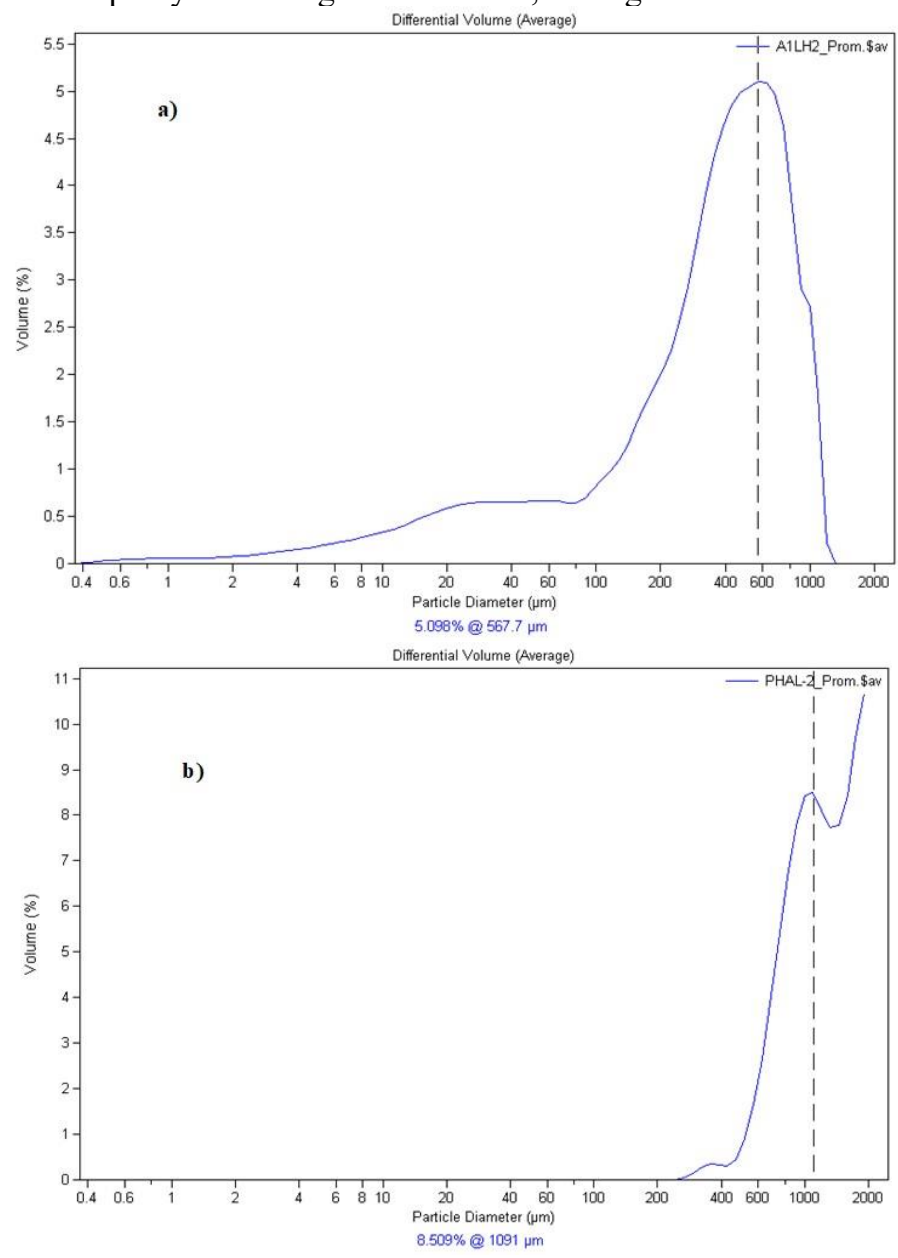

As for the color of the leaves, according to color scale Reyes et al., 2000 with an average value of 3.50, are considered mature and excellent age to be used. These leaves had the lowest number of lateral spines (27 on average) than all other varieties, this due to its smaller relative, but the average height of the apical spine $(1.87 \mathrm{~cm})$ if the parameter corresponds to the authors (Reyes et al., 2000) refer $(\approx 2.0 \mathrm{~cm})$. Fig. 13 shows a photomicrograph of fiber lengths for this range. If the average of all species are compared in terms of particle size on minority fractions $(<0.5 \mathrm{~mm})$, which are those that may be not beneficial when the process of pulping, we see in Table 6 , with sizes between 0.33 to $0.45 \mathrm{~mm}$ overall averages the highest percentages (25.2\% and $41.8 \%$ ) for species A. salmiana and A. lechuguilla correspond; both species are cultivated in the state of Hidalgo. This corresponds to the two species of sheet longer, wider and thicker (A. salmiana) and the shorter, narrower, and thinner (A. lechugilla). Meanwhile the species with the largest and smallest average size (A. angustifolia and A. tequilana respectively) were the percentage of portion in this fraction $<0.5 \mathrm{~mm}$. These two species are more similar from morphological or phenotypical view point. 
Fig. 13. Microphotography of the fiber particles 0.5-1.0 mm, of leaves of Agave lechuguilla Torr., Taken in the Municipality of San Agustín Tlaxiaca, Hidalgo.

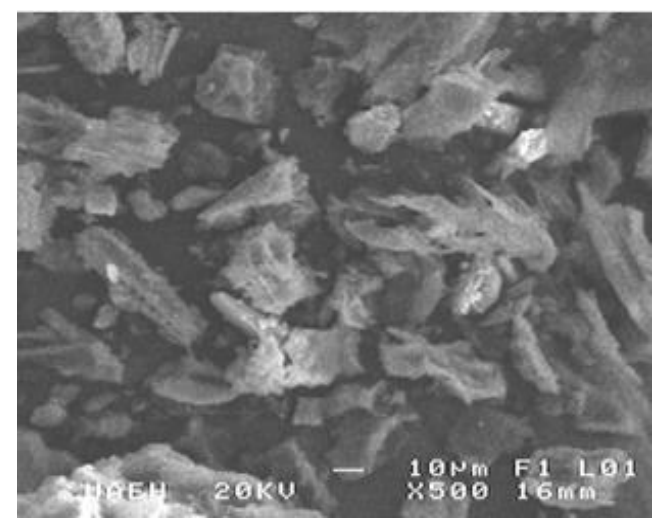

\begin{tabular}{|c|c|c|c|c|}
\hline Plant/leaves & A. angust & A. lechug & $\begin{array}{c}\text { A. } \\
\text { salmian }\end{array}$ & A. tequil \\
\hline Average & 519.37 & 452.45 & 335.68 & 333.33 \\
\hline STA. DES. & 42.181 & 102.029 & 57.022 & 65.155 \\
\hline$\% \mathrm{VC}$ & 8.12 & 22.55 & 16.99 & 19.55 \\
\hline Percentaje & 19.89 & 41.8 & 25.16 & 13.6 \\
\hline
\end{tabular}

\section{CONCLUSION}

From the results of physical characterization and in particular mainly about the sizes of fibers found it can be concluded that there is a high potential for the production of pulp for papermaking. Species A. angustifolia and A. tequilana were presented minor percentage of sizes or fractions $<0.5 \mathrm{~mm}$ that may affect the length of the cellulose fibers after alkaline pulping process. With the A. tequilana fiber $98.5 \%$ $<1 \mathrm{~mm}$ was obtained the majority fraction being the fraction corresponding to $0.5-1.0 \mathrm{~mm}(84.3 \%)$ which corresponds to an almost ideal size for producing cellulosic pulp for making paper. The species $A$. angustifolia showed a $85.06 \%$ fibers $<1 \mathrm{~mm}$ fraction between $0.5-1.0 \mathrm{~mm}$ majority $(65.2 \%)$. The other two species may showed lesser potential for obtaining cellulose pulp for paper. 


\section{REFERENCES}

Aguilar, R.N. 2011. Efecto del almacenamiento de bagazo de caña en las propiedades físicas de celulosa grado papel. Ingeniería Investigación y Tecnología 12(1): 189-197.

Aguirre R.; S. Charcas; F.P. Flores. 2001. El maguey mezcalero potosino. Universidad Autónoma de San Luis Potosí. Consejo Potosino de Ciencia y Tecnología. San Luis Potosí, S.L.P. México. 78 p.

Arriaga, V.V., Y. Cervantes and A. Vargas Mena. 1994. Manual de Reforestación con Especies Nativas: Colecta y Preservación de Semillas, Propagación y Manejo de Plantas. SEDESOL / INE - Facultad de Ciencias UNAM. México, D.F.

Baskin, C.C and J.M. Baskin. 1998. Seeds: ecology, biogeography, and evolution of dormancy and germination. Academic Press, San Diego, California, USA.

Bravo, M.E. 2003. Sugerencias para el manejo integrado del picudo del maguey mezcalero Scyphophorus intertitialis Gyllenhal. Folleto Técnico Número 4. Santo Domingo Barrio Bajo, Etla, Oaxaca, México. p. $1-27$.

Colunga, G.M., A.S. Larqué, Z. Eguiarte, Z.P. Zizumbo. 2007. En lo ancestral hay futuro: del tequila, los mezcales y otros agaves. CICY-CONACYT-CONABIO-INE, México, D.F. 402 pp.

CRT, 2008. (CONSEJO REGULADOR DEL TEQUILA). Informe de las principales actividades enerodiciembre de 2008, Disponible en la dirección: www.crt.org. mx Consultado 10 de marzo de 2014.

Delgado, C. R.; Rodríguez, R.; Capulín, J.; Madariaga, A.; Islas, M. 2022. Physicochemical characterization of saline agricultural soils in the town of Chicavasco, Hidalgo State, Mexico. South Florida Journal of Development. Vol. 3 No. 1. p. 335-344.

DOF, 2011. Ley publicada en el Alcance del Periódico Oficial, el lunes 31 de diciembre de 2011

Enríquez V.J.R, G. Carrillo, J.L. Rodríguez (2005) Sales inorgánicas y ácido indolbutírico en el enraizado in vitro de brotes de Agave angustifolia. Rev. Fitotec. Mex. 28: 175-178.

FAO 1994. FAO Agriculture Series, No. 27. ISSN 0081-4539. Food and Agriculture Organization of the United Nations.

Flores L., M. Byerly, R. Aceves and C. Ruiz. 2002. Diagnóstico del sistema de producción de agave con énfasis en problemas fitosanitarios. pp. 63-95. In Análisis agroecológico de Agave tequilana Weber var. Azul con énfasis en problemas fitosanitarios en Jalisco. Publicación Especial Núm. 1. INIFAP-CIRPACCampo Exp. Altos de Jalisco. Tepatitlán, Jalisco, México.

García Herrera, E.J.; J. Méndez Gallegos and D. Talavera Magaña. 2010. RESPYN Revista Salud Pública y Nutrición, Edición Especial No. 5; (ISSN 1870-0160), 119-129.

García Mendoza, A. 2010. Revisión taxonómica del complejo Agave potatorum Zucc. (Agavaceae): nuevos taxa y neotipificación. Acta Bot. Mex. 91():71-93.

García Mendoza, A. J. 2012. México, país de magueyes. Suplemento "La Jornada del campo". La Jornada, sábado 18 de febrero del 2012, no. 53, p. 4. Versión electrónica: Artículo sobre los distintos tipos de magueyes o mezcales o agaves 
García Mendoza, A.J. 2004. Agaváceas. In: García Mendoza, A.J., Ordóñez, M.J. and Briones Salas M. (eds.). Biodiversidad de Oaxaca, Instituto de Biología, UNAM-Fondo Oaxaqueño para la Conservación de la Naturaleza-World Wildlife Fund, México, D. F. p.p. 159-169.

Gentry, A.H. 1982. Patterns of neotropical plant species diversity. Evolutionary Biology, 15:1-84.

González. M. 1986. Determinación de la Dosis de Ácido 2-cloroetil fosfórico y Época Óptima para la Propagación de Barbasco Dioscorea composita. Tesis profesional (Ingeniero Agrónomo). Facultad de Agricultura, Universidad Autónoma de Guadalajara. Jalisco.

Granados, D. 1993. Los Agaves de México. Universidad Autónoma de Chapingo.

Gutiérrez Uribe, A.J.; L. Santos Zea, A.M. Leal Diaz and E. Cortes Ceballos. 2012 “Agave (Agave spp.) and Its Traditional Products as a Source of Bioactive Compounds," Current Bioactive Compounds, Vol. 8, No. 3, 2012, pp. 218-231.

Hernández, G., D. Canelo and G. Morales. 1991. Estudio de cuatro especies forestales no maderables de los municipios de San Juan de Guadalupe y General Simón Bolívar, Durango (Informe Anual). Programa de Aprovechamiento de Recursos Naturales (PAIR - UNAM). Facultad de Ciencias, UNAM. México, D.F.

Iniguez Covarrubias G., S.E. Lange and R.M. Rowell. 2001. Utilization of byproducts from the tequila industry: part 2 potential value of Agave tequilana Weber azul leaves. Bioresour. Technol. 77:101-108

Martínez L. 2004. Tequila, tradición y destino. Revimundo, México D. F. 165 pp. En: Martínez, M. 1979. Catálogo de Nombres Científicos y Vulgares de Plantas Mexicanas. Fondo de Cultura Económica. México. 1247 p.

Medina G.G., J.C. Ruiz and P. Martínez. 1998. Los Climas de México. Libro Técnico Núm. 1. INIFAP. Ed. Conexión Gráfica. Guadalajara, Jalisco, México. 103 p.

Montañez, S.J.; G.J. Venegas, V.M. Vivar and R.E. Ramos. 2011. Extracción, caracterización y cuantificación de los fructanos contenidos en la cabeza y en las hojas del Agave tequilana Weber Azul. Bioagro. 3(23):199-206.

Mora, C.A. 2012. Caracterización estructural de dos matorrales del noreste de México. Tesis de Maestría. Universidad Autónoma de Nuevo León. Facultad de Ciencias Forestales. Departamento de Silvicultura y Manejo Forestal.

Mora López J.L, J.A. Reyes Agüero, J.L. Flores Flores, C.V. Peña Valdivia and J.R. Aguirre Rivera. 2011. Variación morfológica y humanización de la sección salmianae del género Agave. Agrociencia 45:465467.

NMX-F-211-SCFI-2012. Alimentos-aceites y grasas vegetales o animales-determinacion de humedad y materia volatil por el metodo de placa caliente-metodo de prueba (cancela a la NMX-F-211-SCFI-2006)

Nobel, P. S. 2003. Agave tequilana and tequila. Mildred E. Mathias botanical Garden, UCLA 6(2): 1315 .

Nobel, P.S., G. Castañeda, E. North, B. Pimienta and C. Ruiz. 1998. Temperature influences on leaf CO2 exchange, cell viability and cultivation range for Agave tequilana. Journal of Arid Environments 39:1-9. 
Norma Oficial Mexicana. 1997. NOM- 070-SCFI-1994. Bebidas alcohólicas-mezcal-especificaciones. Palma, F. 1991. El género Agave L. y su distribución en el Estado de Oaxaca. Tesis de Licenciatura, Escuela Nacional de Estudios Profesionales, Iztacala, UNAM.

Parra, L.A.; P. del Villar and A. Prieto. 2010. Extracción de fibras de agave para elaborar papel y artesanías. Acta Universitaria. Vol. 20, Número especial 3, p.77-83.

Peña Valdivia C.B., A.B. Sánchez Urdaneta, J.R. Aguirre, C. Trejo, E. Cárdenas and A. Villegas. 2006. Temperature and mechanical scarification on seed germination of "maguey" (Agave salmiana Otto ex Salm-Dyck). Seed Sci. Technol. 34:47-56.

Pérez, E. and Y.C. Gallardo. 1997. Diagnóstico Botánico-Ecológico General del Parque Zoológico "Zoofari" en el Estado de Morelos. México.

Reyes Agüero, J.A., J.R. Aguirre Rivera and C.B. Peña Valdivia. 2000. Biología aprovechamiento de Agave lechuguilla Torr. Boletín de la Sociedad Botánica de México. Vol. 67, p. 75-88.

Rodríguez, I. M. 2006. Caracterización química de fibras de plantas herbáceas utilizadas para la fabricación de pastas de papel de alta calidad. Tesis Doctoral. Universidad de Sevilla, España.

Rzedowski, J. 1983. Vegetación de México. Editorial Limusa. México.

Sánchez, C, 1989. Principales enfermedades que afectan a Agave angustifolia Haw. y Agave americana L. en el distrito de Tlacolula, Oaxaca. Tesis de Licenciatura, Biólogo. Escuela Nacional de Estudios Profesionales Iztacala, UNAM.

Silos Espino, H., L.L. Valera Montero, C. Perales Segovia, A. Nava Cedillo, J. Méndez Gallegos, A. Amante Orozco and D. Rossel Kipping. 2010. Biotecnología para el semidesierto: Tópicos selectos sobre el cultivo de nopal y maguey. 100 pp. ISBN:978-607-7533-47-4.

Solís Aguilar, J. F., H. González Hernández, J.L. Leyva Vázquez, A. Equihua Martínez, F.J. Flores Mendoza and A. Martínez Garza. 2001. Scyphophorus acupunctatus Gyllenhal, Plaga del agave tequilero en Jalisco, México. Agrociencia 35 (6): 663-670.

Standley, P.C. 1961. Trees and Shrubs of Mexico. United States National Herbarium.

Vargas T. 2004. Evaluación del potencial agroecológico del cultivo de Agave tequilana Weber en el Estado de Jalisco. Tesis de Licenciatura. Universidad de Guadalajara, Facultad de Agronomía. Zapopan, Jalisco. 46 p.

Vázquez Díaz, E., J.R. García Nava, R. Peña Valdivia, H.M. Ramírez Tobías and V. Morales Ramos. 2011. Tamaño de la semilla, emergencia y desarrollo de la plántula de maguey (Agave salmiana Otto ex Salm-Dyck). Revista fitotecnia mexicana, 34(3), 167-173

Velasco, P.; P. Soengas, M. Vilar, M.E. Cartea and M. del Rio, M. 2008. Comparison of glucosinolate profiles in leaf and seed tissues of different Brassica napus crops. J. Am. Soc. Hort. Sci., 133, (4), 551 558.

Yusuf, A. 2018. Agro-morphological characterization of wild safflower (carthamus 1.-asteraceae) species in Turkey. Pak. J. Bot., 50(2): 685-692.

Morpho Zamora, C.; B.I. Juárez, J.R. Aguirre, D.P. Ortiz, C.I. Godínez and G. Álvarez. 2010. Variación de la concentración de azúcares y saponinas durante la cocción del maguey mezcalero potosino. e-Gnosis, vol. 8, p. 1-11. 